\title{
Persistent Organochlorine Compounds Levels in Selected Fish Species from Lake Victoria and Associated Human Health Risks
}

\author{
Alex Wenaty ${ }^{1}{ }^{*}$ Arvid Fromberg ${ }^{2}$, Faith Mabiki ${ }^{3}$, Bernard Chove ${ }^{1}$, Anders Dalsgaard ${ }^{4}$, \\ Robinson Mdegela ${ }^{5}$ \\ ${ }^{1}$ Department of Food Technology, Nutrition and Consumer Sciences, College of Agriculture, Sokoine University of Agriculture, Morogoro, \\ Tanzania \\ ${ }^{2}$ National Food Institute, Technical University of Denmark (DTU), Lyngby, Denmark \\ ${ }^{3}$ Department of Physics and Chemistry, Solomon Mahlangu College of Science and Education, Sokoine University of Agriculture, Morogoro, \\ Tanzania \\ ${ }^{4}$ Department of Veterinary and Animal Sciences, Faculty of Health and Medical Sciences, University of Copenhagen, Frederiksberg, \\ Denmark \\ ${ }^{5}$ Department of Veterinary Medicine and Public Health, College of Veterinary and Biomedical Sciences, Sokoine University of Agriculture, \\ Morogoro, Tanzania
}

Email address:

wenatyalex@sua.ac.tz (A. Wenaty)

${ }^{*}$ Corresponding author

\section{To cite this article:}

Alex Wenaty, Arvid Fromberg, Faith Mabiki, Bernard Chove, Anders Dalsgaard, Robinson Mdegela. Persistent Organochlorine Compounds Levels in Selected Fish Species from Lake Victoria and Associated Human Health Risks. Agriculture, Forestry and Fisheries.

Vol. 8, No. 1, 2019, pp. 1-9. doi: 10.11648/j.aff.20190801.11

Received: December 17, 2018; Accepted: January 14, 2019; Published: January 31, 2019

\begin{abstract}
Nile perch (L. niloticus) and Nile tilapia (O. niloticus) are the major commercial fish species in Lake Victoria region of Tanzania. This study was conducted to assess the levels of persistent organochlorine compounds, namely PCBs and OCPs in these two fish species and the probable human health risks associated with the consumption of these two fish species from Lake Victoria. Fish samples were collected between May and August 2016 and the necessary anthropometric measurements such as length and weight were taken. The extraction was done using a modified QuEChERS method and the identification and quantification of the chemicals were done using GC/ECDs. The results of this study revealed that fish species sampled were undersize, which was an indication of overfishing and abuse of bylaws. Among the 19 OCPs which were considered, only four ( $\beta-\mathrm{HCH}, \mathrm{HCB}$, Aldrin and Dieldrin) were detected at measurable quantities. $\beta$ - $\mathrm{HCH}$ ranged from $<0.24$ to $1.19 \mu \mathrm{g} / \mathrm{kg}$. The mean concentrations were $0.77 \pm 0.43 \mu \mathrm{g} / \mathrm{kg}$ and $0.56 \pm 0.16 \mu \mathrm{g} / \mathrm{kg}$ for L. niloticus and $O$. niloticus respectively. HCB levels ranged from $<0.18$ to $0.59 \mu \mathrm{g} / \mathrm{kg}$ in L. niloticus and $<0.18 \mu \mathrm{g} / \mathrm{kg}$ in $O$. niloticus. Aldrin ranged from $<0.14$ to $0.34 \mu \mathrm{g} / \mathrm{kg}$ in L. niloticus whereas it was not detected in O. niloticus. Moreover, Dieldrin residues ranged from $<0.17$ to $1.06 \mu \mathrm{g} / \mathrm{kg}$ in O. niloticus but were not detected in L. niloticus. Generally, there were slightly higher levels of the detected OCPs in L. niloticus than the corresponding levels in O. niloticus mainly due to their differences in trophic levels and feeding habits. The indicator PCBs were not detected in all the investigated fish samples. The levels of all the detected organochlorines were far below the MRL set for fish and fishery products suggesting that the fresh fish from Lake Victoria are safe for human consumption. Low levels of the detected residues and non- detection of many organochlorines considered indicate that contamination in Lake Victoria has not reached alarming levels. The human health risk assessment of the detected organochlorines showed cancer risk from 8.6E-06 to 3.2E-05 for children and from 7.8E-06 to $1.3 \mathrm{E}-05$ for adults indicating that there is a low cancer risk for both age groups. The non- cancer risks (HI) on the other hand, were 5.7E-02 for children and 4.7E-02 for adults, which is an indication of an insignificant risk.
\end{abstract}


Keywords: Cancer Risks, Hazard Index, Hazard Quotient, Non- Cancer Risks, OCPs, Indicator PCBs

\section{Introduction}

Organochlorine compounds such as polychlorinated biphenyls (PCBs), and organochlorine pesticides (OCPs) such as Dichloro diphenyl trichloroethanes (DDTs), Hexachlorocyclohexanes (HCHs), Hexachlorobenzene (HCB), Aldrin, Dieldin, Endosulfans, Heptachlor and their degradation products in the environment are characterized by their high chemical stability, low water solubility, and low vapour pressure $[1,2]$. Because of these properties PCBs and OCPs are commonly referred to as persistent organic pollutants $[2,3]$; and because of their lipophilic nature, they have the ability of accumulating in fatty tissues of living organisms such as fish $[4,5,6]$. Because of consuming fish, the compounds are likely to accumulate and concentrate in fatty tissues of human beings. Based on the 2015 survey, pesticides which are currently in use on the Tanzanian side of Lake Victoria include Organophosphorous pesticides (OPs), Carbamates (CAs), Pyrethroids and some Organochlorine pesticides (OCPs) such as DDTs, endosulfans, drins, and HCHs. These chemical pesticides have been used mainly in the cotton fields, for horticultural production and in sugarcane plantations. Similar findings have also been reported in previous studies carried out in Lake Victoria [7, 8]. While most of the pesticides are used in agriculture, DDTs is also used to control mosquito populations in the fight against malaria [6]. There is also an increased discharge of medical wastes, industrial, leakages of transformer oils, electronics and domestic wastes that might increase PCBs loading in the aquatic environment [6]. Evidence shows that PCBs have stopped been produced worldwide since 1984; however, several PCB containing materials have been used much longer. However, studies in countries that are sharing Lake Victoria with Tanzania namely, Uganda and Kenya have reported significant quantities of PCBs in water, sediments, and in fish $[9,10,11]$. The compounds are reported to be semi-volatile and this nature has enabled them to move longer distances in the atmosphere before they are finally deposited in the environmental compartments [12]. There is therefore no doubt that fish from the Tanzanian side of Lake Victoria are equally contaminated by PCBs $[6,12]$. The status and extent of pollution of fresh fish from the Tanzanian side of Lake Victoria remains unknown. However, very little has been done to assess the organochlorines residue inputs to the lake's current state of pollution. For example, Henry and Kishimba (2006) assessed the levels of only few organochlorine pesticides (DDTs and endosulfans). No study has been undertaken to investigate the levels of PCBs in fish from the Tanzanian side of Lake Victoria. In this study therefore, despite being the most commonly used pesticides for agriculture OPs, CAs, and Pyrethroids were not considered as a significant problem in fish species. This is because high dilution of the lake and low to moderate half- lives ranging from a few hours to a number of days [13] make it possible for the pesticides to be found in edible fish muscles. There are many organochlorine compounds that exist naturally in the environment and some of these originate from anthropogenic activities. However, it is PCBs and OCPs, which are noted for their persistence and bioaccumulative properties in the environment. This study therefore considered only OCPs and PCBs because of their ability to travel long distances in the atmosphere, and thus they may be found in areas where they have never been produced or used [12]. They are also characterized by high solubility in lipids and high chemical stability, characteristics which have resulted into their widespread distribution in almost all environmental media such as air, water, soil, rain, and the biota $[6,12]$. For PCBs, the study considered only the 7 indicator PCBs because they are known to be more persistent and bioaccumulative in the environment and food items than is the case for other congeners. They are therefore assumed to be suitable representatives of all PCBs. This study as far as we know is the first of its kind to assess the concentrations of a range of persistent organochlorine compounds in commercial fish species from Lake Victoria in Tanzania.

\section{Materials and Methods}

\subsection{Description of the Study Area}

Lake Victoria is a trans-boundary lake shared between Tanzania (51\%), Uganda (43\%) and Kenya (6\%). It is the World's second largest lake with the approximated total surface area of $68,800 \mathrm{~km}^{2}$ after Lake Superior of North America $[9,10]$. The lake supports one of the World's most productive inland species of fisheries of commercial value such as Nile perch, Nile tilapia, and other species. The highly caught and consumed fish species at international and domestic markets are Nile perch (Lates niloticus) and Nile tilapia (Oreochromis niloticus) respectively $[9,10]$.

In Tanzania, the lake is shared by five Regions, namely; Mwanza, Mara, Kagera, Geita, and Simiyu (Figure 1). 


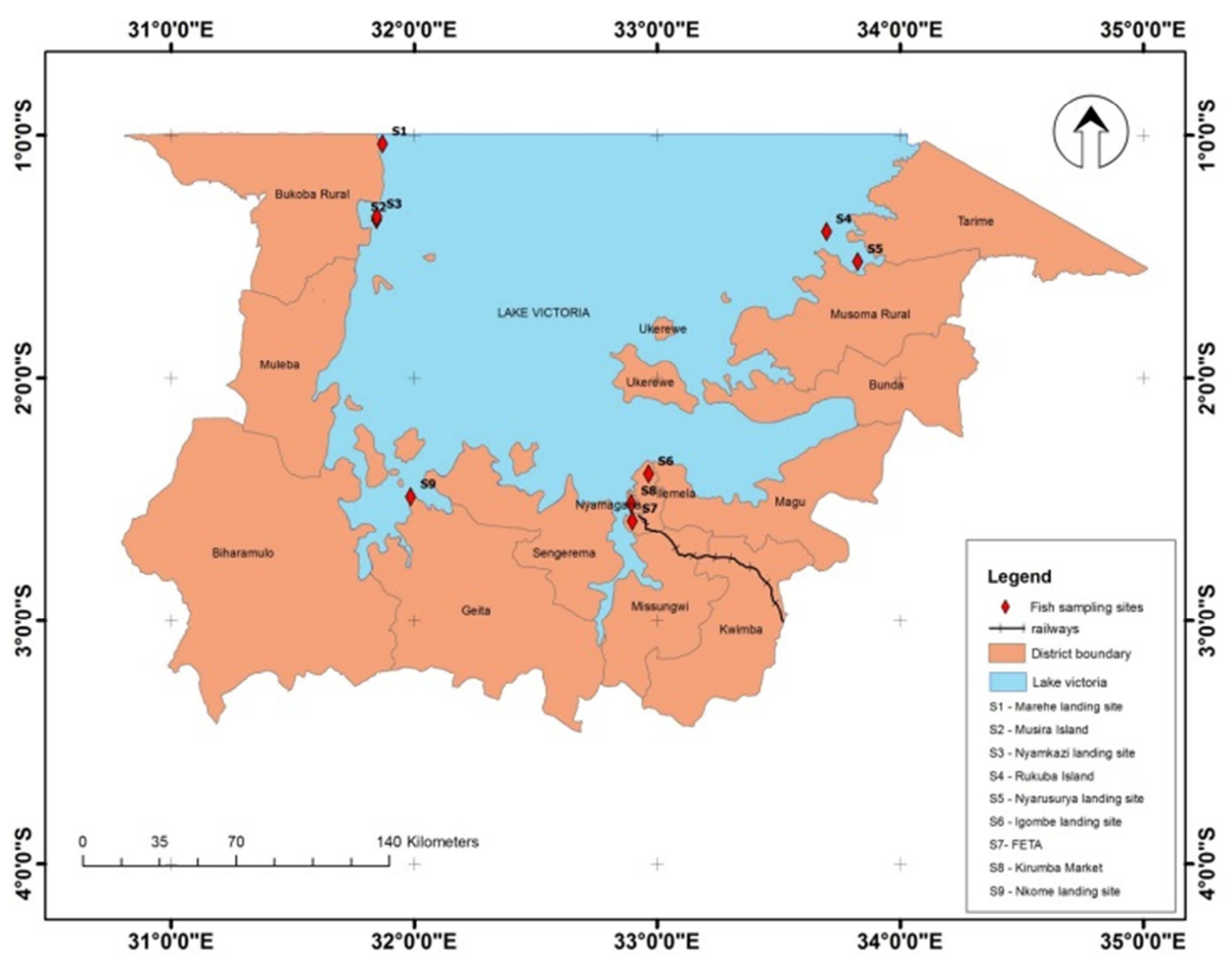

Figure 1. A map showing Tanzanian side of Lake Victoria and sampling points.

\subsection{Ethical Clearance and Permissions}

The permission to conduct this study in Lake Victoria, Tanzania was given by the Ethics and Research Committee of Sokoine University of Agriculture (SUA) and the respective Regional Administrative Secretaries (RAS) in the Regions where fish samples were collected. The export permit of samples was granted by the Tanzanian Ministry of Agriculture, Food Security, Livestock Development and Fisheries. The permission of importing samples to Denmark was given by the Danish Veterinary and Food Administration.

\subsection{Sampling and Fish Information}

Two major commercial fish species namely, Nile perch ( $L$. niloticus) and Nile tilapia (O. niloticus), which are commonly found in Lake Victoria with different feeding habits and trophic levels were sampled for PCBs and OCPs analysis. Nile perch (L. niloticus) is a carnivorous species while Nile tilapia (O. niloticus) is an omnivorous species. The fish were collected from nine selected nationally designated sampling stations in seven districts on the Tanzanian side of Lake Victoria. The districts include Nyamagana, Ilemela (in Mwanza), Geita (in Geita), Rorya and Musoma (in Mara) and Bukoba Rural and Bukoba Municipal (in Kagera).

A total of 162 fish samples (81 L.niloticus and $81 O$. niloticus samples i.e. 9 fish per site per species) were collected from randomly selected fishermen at landing sites along Lake Victoria between May and August 2016. The weights and lengths of the sampled fish species were determined using a beam balance and a ruler respectively. The fish were stored in a cool box at $4^{\circ} \mathrm{C}$ and transported to the laboratory for deep freezing at $-18^{\circ} \mathrm{C}$ until extraction.

\subsection{Laboratory Preparation of Fish Samples and Quality of Analytical Reagents}

Samples were prepared at the National Fish Quality Control Laboratory (NFQCL) in Mwanza, Tanzania. All the reagents and glassware were purchased from local suppliers in Tanzania and were of analytical grade. Fish samples extraction and cleanup for determination of organochlorine compounds were done using a modified QuEChERS procedure [14] at the National Fish Quality Control Laboratory in Mwanza, Tanzania. Three samples of almost the same size and weight [15] from the same sampling location, and the same species were pooled and homogenized to form a single composite sample [6]. Thirty grams of each sample were measured in triplicates $(3 \times 30 \mathrm{~g})$ and ground using a motor and a pestle to homogenize. Fifteen grams of composite samples were transferred into $100 \mathrm{~mL}$ centrifuge tubes. Thereafter, $2.5 \mathrm{~g}$ of sodium bicarbonate $\left(\mathrm{NaHCO}_{3}\right), 60 \mathrm{~mL}$ of ethyl acetate 
and $15 \mathrm{~g}$ of anhydrous $\mathrm{Na}_{2} \mathrm{SO}_{4}$ were added and placed in a shaker to homogenize for 10 minutes. The supernatants were transferred into $15 \mathrm{~mL}$ centrifuge tubes containing $0.125 \mathrm{~g}$ of Primary Secondary Amine (PSA) and $0.75 \mathrm{~g}$ of anhydrous $\mathrm{MgSO}_{4}$ [14]. The mixture was centrifuged at $2500 \mathrm{rpm}$ for 20 minutes and left to separate for further 10 minutes. The resulting supernatants $(2 \mathrm{~mL})$ were transferred into vials and transported to Denmark Technical University (DTU), Division of Food Analytical Chemistry for GC analysis. Prior to GC analysis, the supernatants were evaporated with a gently stream of nitrogen to almost dryness to assess the lipid content and concentrate the analytes. Supernatants with large amounts of lipids were further cleaned as follows; the extract was transferred to an Agilent EMR Lipid dSPE $15 \mathrm{~mL}$ tube, vortexed and centrifuged for $10 \mathrm{~min}$. Polishing salts from an Agilent EMR $\mathrm{MgSO}_{4}$ polish pouche were added, vortexed and shaken immediately. The samples were centrifuged and an aliquot was transferred to a micro centrifuge tube containing Agilent EMR $\mathrm{MgSO}_{4}$ polish and centrifuged at $5000 \mathrm{rpm}$ for $10 \mathrm{~min}$. The supernatant was finally transferred to a GC vial, eluted with isooctane and internal standards were added for GC analysis.

\subsection{Analytical Quality Control and Limits of Detection (LODs)}

To maintain the quality of analytical results, blanks and standards were run after every 5 samples. The limits of detection (LODs) were calculated as concentrations whose peaks were three times the peaks of signal to noise $(\mathrm{S} / \mathrm{N})$ ratio, whereas the corresponding limits of quantification (LOQs) were calculated as concentrations using the peaks which were ten times the peaks of signal to noise $(\mathrm{S} / \mathrm{N})$ ratios. The LOD values for PCBs ranged from $0.09 \mu \mathrm{g} / \mathrm{kg}$ (CB 180) to $0.18 \mu \mathrm{g} / \mathrm{kg}$ (CB 52) while the LOQ values were from $0.31 \mu \mathrm{g} / \mathrm{kg}$ (CB 180) to $0.60 \mu \mathrm{g} / \mathrm{kg}$ (CB 52). For OCPs, the LOD values ranged from $0.10 \mu \mathrm{g} / \mathrm{kg}$ (Isodrin) to $0.24 \mu \mathrm{g} / \mathrm{kg}(\beta-\mathrm{HCH})$ and the LOQ values ranged from $0.37 \mu \mathrm{g} / \mathrm{kg}$ (Isodrin) to $0.79 \mu \mathrm{g} / \mathrm{kg}(\beta-\mathrm{HCH})$.

\subsection{Chemical Analysis}

Chemical analysis was performed at the laboratory of Food Analytical Chemistry, at the Technical University of Denmark (DTU), Denmark. The collected samples of fish were analyzed for 19 OCPs namely; p, p- DDT, o, p- DDT and metabolites $\mathrm{p}, \mathrm{p}-\mathrm{DDE}$ and $\mathrm{p}, \mathrm{p}-\mathrm{DDD}, \alpha-\mathrm{HCH}, \beta-$ $\mathrm{HCH}, \gamma-\mathrm{HCH}$ (lindane), HCB, Heptachlor, Heptachlor epoxide, Aldrin, Dieldrin, Endrin, Isodrin, $\alpha-$ Endosulfan, Oxychlordane, $\gamma-$ Chlordane, $\alpha-$ Chlordane and Transnonachlor and 7 indicatory polychlorinated biphenyls ( $57 \mathrm{PCB}$ ); with IUPAC numbers: CB 28, CB 52, CB 101, CB 118, CB 138, CB 153 and CB 180.The 7 indicator PCB congeners were chosen based on their persistence in food web and their tendency to biomagnification. Most of the studied compounds are listed in the Stockholm Convention on POPs for initial elimination and reduction in the use because of their effects on the environment as well as in living organisms.

\subsection{Detection of PCBs and OCPs Using Gas Chromatography}

The separation and detection of OCPs were performed on a Hewlett Packard Gas Chromatography (Agilent 6890 Series gas chromatography system; Agilent Technologies) which was equipped with an autosampler (Agilent 7683 Series; Agilent Technologies). For optimum separation, a dual capillary column system with two separate columns of different polarity and selectivity (Chrompac $\mathrm{CP}-$ sil $5 \mathrm{CB}$ and J \& W DB- 17) were used, with nominal length of $50 \mathrm{~m}$ and $60 \mathrm{~m}$ respectively, $0.25 \mathrm{~mm}$ ID, $0.25 \mu \mathrm{m}$ film thickness) and coupled with two ${ }^{63} \mathrm{Ni}$ electron capture detectors (Agilent 6890 ECD). The following GC conditions were used: Injector temperature: $280^{\circ} \mathrm{C}$; injection volume: $2 \mu \mathrm{L}$; injector mode: splitless; purge flow: $42 \mathrm{~mL} / \mathrm{min}$; purge time: $0.60 \mathrm{~min}$; carrier gas: Helium; constant flow: $2.0 \mathrm{~mL} / \mathrm{min}$ and $1.3 \mathrm{~mL} / \mathrm{min}$ respectively and make up gas: Nitrogen. The temperature programme was $90^{\circ} \mathrm{C}$ held for 2.0minutes; $30^{\circ} \mathrm{C} / \mathrm{min}$ increased to $170^{\circ} \mathrm{C}$ and held for 7.5 minutes; $2.0^{\circ} \mathrm{C} / \mathrm{min}$ increased to $185^{\circ} \mathrm{C} ; 3.0^{\circ} \mathrm{C} / \mathrm{min}$ increased to $220^{\circ} \mathrm{C}$ and held for 15 minutes; $3.0^{\circ} \mathrm{C} / \mathrm{min}$ increased to $255^{\circ} \mathrm{C}$ and held for 2 minutes and $5.0^{\circ} \mathrm{C} / \mathrm{min}$ increased to $280^{\circ} \mathrm{C}$ and held for 10 minutes. The detector temperature was $300^{\circ} \mathrm{C}$.

\subsection{Data Analysis}

The measured organochlorine compounds data were subjected to descriptive statistics for the deduction of minimum, maximum, mean concentrations and standard deviations. The data were further subjected to SPSS Version 16.1. Data on organochlorine compounds concentrations were presented as mean $\pm \mathrm{SD}$; and One - way ANOVA was used to compare concentrations between species and means were separated using Duncan's Multiple Range Test. In data processing, the concentrations of organochlorines in the samples below the limit of detection $(<\mathrm{LOD})$ were treated as zero. Significance was declared at $\mathrm{p}<0.05$ for all analyses.

\subsection{Human Health Risk Assessment Model}

Cancer and Non- cancer risk assessments were performed using the existing models reported in literature. The estimated dose (CDI) which was received through the consumption of fresh fish muscles was calculated using equation (1); and the cancer risk $\left(C_{R}\right)$ was calculated using equation (2), which was adopted from the Environmental Protection Agency of the United States [16, 17, 18].

$$
\begin{gathered}
C D I=\frac{C * C R * E F * E D}{B W * A T} \\
\mathrm{C}_{\mathrm{R}}=\mathrm{SF} * \mathrm{CDI}
\end{gathered}
$$

For non-carcinogenic risks, the hazard quotients (HQs) of each measured compound was calculated using equation (3) 


$$
H Q=\frac{C D I}{R f D}
$$

Where;

$\mathrm{CDI}(\mathrm{mg} / \mathrm{kg}$-day) is the estimated chronic daily intake

$C_{R}$ is the cancer risk via consumption of contaminated fish

$\mathrm{C}(\mathrm{mg} / \mathrm{kg})$ is the measured concentration of organochlorine compounds in fish

$\mathrm{CR}(\mathrm{kg} /$ day) is the consumption rate

$\mathrm{EF}$ is the exposure frequency, 365days/year [19]

ED is the exposure duration, 60years for adults and 12years for children [19].

$\mathrm{SF}$ is the cancer slope factor, in this study, $2(\mathrm{mg} / \mathrm{kg} \text {-day })^{-1}$

[20] for all OCPs which were detected in this study.

$\mathrm{RfD}$ is the Reference Dose (mg/kg-day), which varied from one organochlorine pesticide to another.

BW is the hypothetical average body weight, in this study, $70 \mathrm{~kg}$ was BW for adults and $29 \mathrm{~kg}$ was BW for children [21].

$\mathrm{AT}$ is the averaging time, 60years* 365days/year $=$ 21900 days for adults and 12 years* 365 days $/$ year $=4380$ days for children [20, 21].

Qualitative descriptions of lifetime cancer risks were based on ATSDR standards as follows; very low when the estimated value is $\leq 10 \mathrm{E}-06$, low when $10 \mathrm{E}-06<$ value $\leq 10 \mathrm{E}$ 04 , moderate when $10 \mathrm{E}-04<$ value $\leq 10 \mathrm{E}-03$, high when $10 \mathrm{E}$ $03<$ value $\leq 10 \mathrm{E}-01$, and very high when the estimated value is $\geq 10 \mathrm{E}-01[18,20,22]$. For non- carcinogenic risks, hazard index (HI) greater than one was considered as risky while $\mathrm{HI}$ less than one was considered as no risk associated with the consumption of fish products.

\section{Results and Discussion}

\subsection{Fish Characteristics}

The mean weights and lengths of the fish collected from the nine sampling stations are shown in Table 1 . The mean length ranged from 23.0 to $27.0 \mathrm{~cm}$ for Nile perch $(L$. niloticus) and from 22.0 to $25.0 \mathrm{~cm}$ for Nile tilapia $(O$. niloticus). The weights of the sampled fish ranged from 811.0 to $951.0 \mathrm{~g}$ and from 776.0 to $862.0 \mathrm{~g}$ for L. niloticus and $O$. niloticus respectively. The information which was collected from fish inspectors in Lake Victoria indicates that fish species between 50 and $85 \mathrm{~cm}$ are of reasonable size to be caught for human consumption; whereas fish sizes of below $50 \mathrm{~cm}$ are undersize and are therefore not allowed to be caught. Moreover, fish above $85 \mathrm{~cm}$ are oversize and therefore are not allowed for fishing. There were no significant differences in the mean lengths and weights between fish species across the investigated sites. In this study therefore, all the collected fish samples were undersize as their mean lengths were below $50 \mathrm{~cm}$ implying that there was overfishing and which was in violation of the set bylaws in Lake Victoria. Though the age of fish was not determined, previous studies have reported that the length of fish is directly related to its age and that age has great influence on the bioaccumulation of the investigated organochlorinated compounds in fish [6]. And the longer the fish lives in a contaminated aquatic environment, the more the organochlorine compounds it accumulates; this is because the available evidence shows that organochlorine compounds tend to biomagnify with time $[9,23,24]$.

Table 1. Data of fresh fish samples collected from nine sampling sites of Lake Victoria, Tanzania.

\begin{tabular}{|c|c|c|c|c|}
\hline & Fish species & & & \\
\hline & L. niloticus & & O. niloticus & \\
\hline Sites & Mean length (cm) & Mean weight (g) & Mean length (cm) & Mean weight (g) \\
\hline S1 & $27.0 \pm 10.1$ & $860.0 \pm 549.1$ & $23.0 \pm 5.4$ & $776.0 \pm 303.0$ \\
\hline S2 & $25.3 \pm 9.0$ & $840.4 \pm 543.1$ & $25.0 \pm 8.0$ & $853.0 \pm 378.0$ \\
\hline S3 & $26.0 \pm 8.3$ & $811.1 \pm 521.4$ & $24.3 \pm 6.0$ & $844.0 \pm 328.0$ \\
\hline S4 & $26.0 \pm 9.0$ & $876.0 \pm 545.0$ & $25.0 \pm 6.1$ & $862.2 \pm 332.0$ \\
\hline S5 & $25.4 \pm 9.0$ & $908.1 \pm 538.0$ & $24.4 \pm 6.1$ & $846.2 \pm 327.0$ \\
\hline S6 & $25.3 \pm 8.1$ & $922.2 \pm 513.0$ & $24.2 \pm 6.0$ & $824.0 \pm 300.0$ \\
\hline S7 & $23.0 \pm 9.0$ & $842.1 \pm 502.0$ & $22.4 \pm 8.2$ & $816.0 \pm 348.4$ \\
\hline S8 & $26.0 \pm 8.2$ & $951.0 \pm 480.1$ & $25.0 \pm 7.0$ & $856.0 \pm 356.0$ \\
\hline S9 & $26.0 \pm 8.4$ & $950.0 \pm 469.1$ & $24.0 \pm 7.3$ & $862.0 \pm 374.0$ \\
\hline
\end{tabular}

\subsection{Levels of Organochlorine Compounds in Fresh Fish Species from Lake Victoria}

The concentrations of OCPs and indicator PCBs in both $L$. niloticus and $O$. niloticus from Tanzanian side of Lake Victoria are presented in Table 2 and in Figure 2. Among the 19 organochlorine pesticides which were considered in this study, only four ( $\beta-\mathrm{HCH}, \mathrm{HCB}$, Aldrin, and Dieldrin) were detected at varying quantities in few samples of both $L$. niloticus and $O$. niloticus. Table 2 also presents the percentage occurrence ( $\%$ Occ.) of each of the detected organochlorine compounds whereby $\beta-\mathrm{HCH}$ was more prevalent than all other chemicals which were measured in this study. $\beta-\mathrm{HCH}$ was detected in $13 \%$ of all the samples considered in this study; whereas each of the other three (HCB, Aldrin, and Dieldrin) was detected in $2 \%$ of the investigated fish samples. For the three $\mathrm{HCH}$ isomers; $\alpha$ $\mathrm{HCH}, \beta-\mathrm{HCH}$, and $\gamma-\mathrm{HCH}$ (lindane), which were considered in this study, only one isomer; $\beta-\mathrm{HCH}$ was detected at measurable levels in fish species at varying quantities. $\beta$ $\mathrm{HCH}$ was detected at S4, S7, and S8. The levels of $\beta-\mathrm{HCH}$ ranged from $<0.24$ to $1.19 \mu \mathrm{g} / \mathrm{kg}$ with a mean concentration of $0.77 \pm 0.43 \mu \mathrm{g} / \mathrm{kg}$ for L. niloticus. For O. niloticus, $\beta$ - $\mathrm{HCH}$ was detected in composite samples from S7 and S8 only with a mean concentration ranging from $<0.24$ to $0.56 \pm 0.16 \mu \mathrm{g} / \mathrm{kg}$. $\beta-\mathrm{HCH}$ in fish samples from the rest of the sampling sites were below their lowest limits of detection ( $<$ LODs). 
The levels of HCHs in both L. niloticus and O. niloticus which were established in this study are far lower than those which were established by Ssebugere et al. [9, 10] in the Ugandan side of Lake Victoria where the concentrations in L. niloticus ranged from $5.7 \mu \mathrm{g} / \mathrm{kg}$ to $26 \mu \mathrm{g} / \mathrm{kg}$, from $7 \mu \mathrm{g} / \mathrm{kg}$ to $34 \mu \mathrm{g} / \mathrm{kg}$, and from $5 \mu \mathrm{g} / \mathrm{kg}$ to $13 \mu \mathrm{g} / \mathrm{kg}$ for $\alpha-\mathrm{HCH}, \beta-\mathrm{HCH}$, and $\gamma-\mathrm{HCH}$ isomers respectively. The other two isomers, $\alpha-\mathrm{HCH}$ and $\gamma-\mathrm{HCH}$ were not detected in any composite fish sample from Lake Victoria. The detection of $\beta-\mathrm{HCH}$ in fish muscles in the present study could therefore be attributed by the fact that $\beta-\mathrm{HCH}$ is more persistent in the environment than other isomers. Studies elsewhere have reported that the environmental persistence of $\beta-\mathrm{HCH}$ is a result of its lower solubility in water and vapour pressure. Furthermore, $\beta-\mathrm{HCH}$ is reported to have $10-30$ times higher the ability of accumulating fatty tissues [25] than is the case with other $\mathrm{HCH}$ isomers. The detection of higher levels of $\beta-\mathrm{HCH}$ isomer than the parent $\gamma-\mathrm{HCH}$ (lindane) in the present study suggests that there is a long history of the use of the pesticide in Lake Victoria catchment area.

The $\sum \mathrm{HCH}$ values in the present study were $2.32 \mu \mathrm{g} / \mathrm{kg}$ for L. niloticus and $1.92 \mu \mathrm{g} / \mathrm{kg}$ forO. niloticus. The $\mathrm{HCH}$ values were far lower than those reported in the fish from Napoleon Gulf in Uganda; $14.95 \mu \mathrm{g} / \mathrm{kg}$ to $45.9 \mu \mathrm{g} / \mathrm{kg}$ [10] and Tana and Sabaki River in Kenya [26]. Furthermore, studies in Ghana reported $\mathrm{HCH}$ residues, which ranged from $0.7 \mu \mathrm{g} / \mathrm{kg}$ to $13.6 \mu \mathrm{g} / \mathrm{kg}$ in fish (Tilapia zilli) from Lake Bosomtwi [3]. Therefore, the results herein were $6-$ 7 folds lower than those established by Darko and others. Studies have reported that $\alpha-\mathrm{HCH} / \gamma-\mathrm{HCH}$ ratios are commonly used to ascertain whether there is a recent input of technical $\mathrm{HCH}$ in the environment and in food items or whether the environmental degradation of technical $\mathrm{HCH}$ is significant [27]. For this study, the ratios were not established since both $\alpha-\mathrm{HCH}$ and $\gamma-\mathrm{HCH}$ were not detected in fish species. The $\mathrm{HCH}$ levels in the fish from Lake Victoria were below the extraneous residue limit (EMRL) of $5,000 \mu \mathrm{g} / \mathrm{kg}$ which is recommended by FAO/WHO Codex Alimentarius Commission for fish and other fisheries products [28]. In respect of $\mathrm{HCHs}$, the results from the present study show no indication of human health risks associated with the consumption of fish from Lake Victoria.

HCB was also observed in the samples of L. niloticus which were collected from 1 sampling site (S3) but was not detected (ND) in all the other sites. The concentration of $\mathrm{HCB}$ ranged from $<0.18$ to $0.59 \mu \mathrm{g} / \mathrm{kg}$. HCB was not detected in all composite samples of $O$. niloticus; and HCB levels were lower than those studied by Polder et al. [6] in other lakes in Tanzania whereby the concentrations of $\mathrm{HCB}$ in $O$. niloticus ranged from $1.4-4.0 \mu \mathrm{g} / \mathrm{kg}$ (L. Victoria), from $1.1-1.3 \mu \mathrm{g} / \mathrm{kg}$ (L. Tanganyika), from 1.2 $2.9 \mu \mathrm{g} / \mathrm{kg}$ (L. Nyasa), and from $0.6-2.8 \mu \mathrm{g} / \mathrm{kg}$ (L. Babati). This may possibly indicate that, $\mathrm{HCB}$ in Tanzanian fish reflects a general background level related to a long range atmospheric transport (LRAT) rather than to local sources.
The HCB levels in the current study were also 4 folds lower $(2.1 \mu \mathrm{g} / \mathrm{kg})$ than those in red- belly tilapia (Tilapia zilli) which are found in Ghana [3]. HCB is reported to have mainly been used as a fungicide, also generated as a byproduct during the production and usage of agrochemicals and industrial chemicals and released into the environment by waste incineration. $\mathrm{HCB}$ is also known to be volatile in nature which can lead to their long range environmental movement [29]. Since there is no evidence that HCB was used as a fungicide in the study area [30], the occurrence of relatively small concentrations of HCB in fish muscles in the current study is probably attributed to the volatile nature and environmental persistence of $\mathrm{HCB}$. The HCB levels in fish in this study were far lower than the tolerable limit of $200 \mu \mathrm{g} / \mathrm{kg}$ set by $\mathrm{FAO} / \mathrm{WHO}$ for fish and other fishery products.

Aldrin residues in L. niloticus were detected at $\mathrm{S} 4$ and its concentration ranged from $<0.14$ to $0.34 \mu \mathrm{g} / \mathrm{kg}$ ). For $O$. niloticus, all investigated sites had levels of Aldrin below their lowest limits of detection $(<0.14 \mu \mathrm{g} / \mathrm{kg})$. Dieldrin residues were observed at $\mathrm{S} 4$ ranging from $<0.17$ to $1.06 \mu \mathrm{g} / \mathrm{kg}$ for $O$. niloticus fish species. For the samples of $L$. niloticus, Dieldrin residues were not detected at any sample. The levels of drins which were established in the current study are by far lower than those detected by Ssebugere et al. [15] in the fish from Ugandan side of Lake Victoria whereby Aldrin and Dieldrin were detected at a concentration of $1.79 \mu \mathrm{g} / \mathrm{kg}$ and $1.17 \mu \mathrm{g} / \mathrm{kg}$ in L. niloticus and $1.88 \mu \mathrm{g} / \mathrm{kg}$ and $2.22 \mu \mathrm{g} / \mathrm{kg}$ in $O$. niloticus respectively. The $\sum$ dieldrin/aldrin ratio for this study was 3.12 . The comparison of the total Dieldrin to the total Aldrin ratio ( $\sum$ dieldrin/aldrin) in fish gave a value greater than 1 , indicating that the detected residues were not likely to be from the recent applications of Aldrin. A similar trend was observed in the water in the Kenyan side of Lake Victoria [31]. Aldrin is readily converted to Dieldrin once it enters either the environment or the body of an organism by the action of sunlight and bacteria in the environment. Therefore, with recent applications of Aldrin, higher levels of Aldrin than Dieldrin and smaller levels of Dieldrin to Aldrin ratio (Ratio $<1$ ) could be expected. However, the concentrations of both Aldrin and Dieldrin in fish for the current study were below the residual limit of $200 \mu \mathrm{g} / \mathrm{kg}$ which was set by competent authorities for fish and fishery products. Figure 2 shows the variations of the detected organochlorine pesticides in the fish species from Lake Victoria. The results of the current study show that the levels of the detected residues were higher in L. niloticus than in the corresponding levels in O. niloticus except for Dieldrin which occurred at a higher level in O. niloticus than in L. niloticus. The differences in the levels of the detected residues are probably due to the differences in trophic levels and feeding habits of the investigated fish species. These observations have been reported in several other previous studies $[6,9,10,11]$.

The 7 indicator PCBs which were considered in this study were not detected (ND) in all the investigated fish species. This 
observation is in contrast with observations in other previous studies which were carried out in the nearby countries, despite sharing of the same Lake Victoria with Kenya and Uganda where fish species have been reported to be contaminated with PCBs [9, 10, 11]. Non detection of indicator PCBs on the Tanzanian side of Lake Victoria is probably either because the aquatic environment is not alarmingly contaminated with PCBs or because the sizes of the sampled fish were small (Table 1). Most of the sampled fish species were undersize; and different studies have reported that the accumulation of most persistent organochlorine compounds including PCBs is directly related to the size of the fish under study [6]. Large sized species tend to accumulate more of these compounds as opposed to small sized species.

Table 2. Concentrations ( $\mu \mathrm{g} / \mathrm{kg}$ ) of organochlorine compounds in fish species from Lake Victoria.

\begin{tabular}{|c|c|c|c|c|c|c|c|c|c|c|c|c|}
\hline Sites & Species & $\beta-\mathrm{HCH}$ & HCB & Aldrin & Dieldrin & CB28 & CB52 & CB101 & CB 118 & CB 138 & CB153 & CB 180 \\
\hline \multirow{2}{*}{ S1 } & L. niloticus & ND & $\mathrm{ND}$ & ND & ND & ND & $\mathrm{ND}$ & ND & $\mathrm{ND}$ & $\mathrm{ND}$ & $\mathrm{ND}$ & ND \\
\hline & O. niloticus & ND & ND & ND & ND & ND & ND & ND & ND & ND & ND & ND \\
\hline \multirow{2}{*}{ S2 } & L. niloticus & ND & ND & ND & ND & ND & ND & ND & ND & ND & ND & ND \\
\hline & O. niloticus & ND & $\mathrm{ND}$ & ND & ND & ND & ND & ND & ND & ND & ND & ND \\
\hline \multirow{2}{*}{ S3 } & L. niloticus & ND & $0.59 \pm 0.0$ & ND & ND & ND & ND & ND & ND & ND & ND & ND \\
\hline & O. niloticus & ND & ND & ND & ND & ND & ND & ND & ND & ND & ND & ND \\
\hline \multirow{2}{*}{ S4 } & L. niloticus & $1.19 \pm 0.0$ & ND & $0.34 \pm 0.0$ & ND & ND & ND & ND & ND & ND & ND & ND \\
\hline & O. niloticus & ND & ND & $\mathrm{ND}$ & ND & ND & ND & ND & ND & ND & ND & ND \\
\hline \multirow{2}{*}{ S5 } & L. niloticus & ND & ND & ND & ND & ND & ND & ND & ND & ND & ND & ND \\
\hline & O. niloticus & ND & ND & ND & ND & ND & ND & ND & ND & ND & ND & ND \\
\hline \multirow{2}{*}{ S6 } & L. niloticus & ND & ND & ND & ND & ND & ND & ND & ND & ND & ND & ND \\
\hline & O. niloticus & $\mathrm{ND}$ & ND & ND & $1.06 \pm 0.0$ & ND & ND & ND & ND & ND & ND & ND \\
\hline \multirow{2}{*}{ S7 } & L. niloticus & $0.79 \pm 0.0$ & ND & ND & ND & ND & ND & ND & ND & ND & ND & ND \\
\hline & O. niloticus & $0.33 \pm 0.0$ & ND & ND & ND & ND & ND & ND & ND & ND & ND & ND \\
\hline \multirow{2}{*}{ S8 } & L. niloticus & $0.34 \pm 0.0$ & ND & ND & ND & ND & ND & ND & ND & ND & ND & ND \\
\hline & O. niloticus & $0.60 \pm 0.0$ & ND & ND & ND & ND & ND & ND & ND & ND & ND & ND \\
\hline \multirow{2}{*}{ S9 } & L. niloticus & ND & ND & ND & ND & ND & ND & ND & ND & ND & ND & ND \\
\hline & O. niloticus & ND & ND & ND & ND & ND & ND & ND & ND & ND & ND & ND \\
\hline$\%$ Occ. & & 13.0 & 2.0 & 2.0 & 2.0 & ND & ND & ND & ND & ND & ND & ND \\
\hline
\end{tabular}

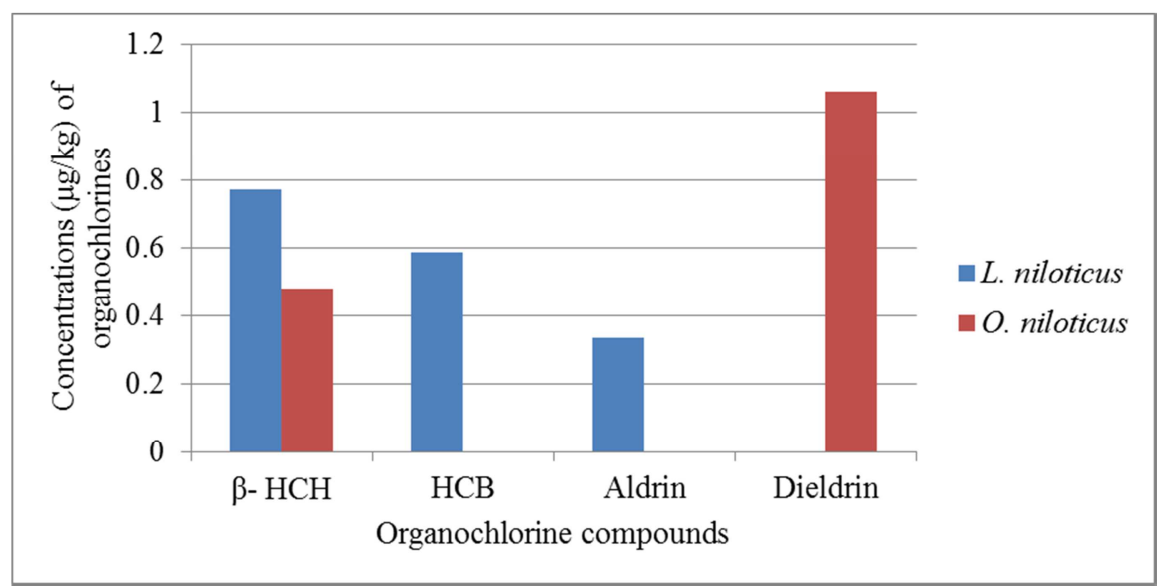

Figure 2. Variations of the detected organochlorine compounds in fish species.

\subsection{Comparison of the Detected Organochlorine Compounds Residue Levels to International Standards}

The comparison of the mean concentrations of the detected organochlorine compounds in fresh frish from Lake Victoria reported in the present study with the maximum residue limit (MRL) recommended by some International statutory bodies [12] is provided in Table 3. In the European Union (EU), there are no specifications for MRL regarding OCPs in fish and fish products. If we consider fat contained in meat and meat products, then the highest admisible residue limits of
OCPs according to the Regulation of the Ministry of Health of 2007 in Poland are $200 \mu \mathrm{g} / \mathrm{kg}$ for Aldrin, Dieldrin, and $\mathrm{HCB}$ and $100 \mu \mathrm{g} / \mathrm{kg}$ for $\beta-\mathrm{HCH}$ [32]. It is generally noted that the mean residue levels of the organochlorine compounds in the investigated fresh fish from Lake Victoria were far below the MRL set by the Food and Agricultural Organization (FAO) of the United Nations (Table 3) for fish and other fishery products. The results therefore imply that the studied organochlorine compounds may not pose health hazards to humans. 
Table 3. Comparison of the concentrations $(\mu \mathrm{g} / \mathrm{kg}$ ) of organochlorine compounds detected in this study with the maximum residue limits (MRL) recommended by some competent International Statutory Agencies.

\begin{tabular}{llll}
\hline Compound & This work & Witczak and Tomza- Marciniak, 2010 & FAO/WHO, 1997 \\
\hline Aldrin & 0.34 & 200 & 300 \\
Dieldrin & 1.06 & 200 & 300 \\
$\beta-$ HCH & 3.25 & 100 & 300 \\
HCB & 0.59 & 200 & 200 \\
\hline
\end{tabular}

\subsection{Probable Human Health Risks}

Table 4 provides the probable quantitative risks to human health associated with the consumption of fresh fish muscles from Lake Victoria. The cancer risks were between 7.8E-06 and 1.3E-05 for adults and between 8.6E-06 and 3.2E-05 for children. According to the recommendations by the Agency for Toxic Substances and Disease Registry [22], the United States Environmental Protection Agency [21] and other studies $[18,20]$; the cancer risk values ranged from10E-06 to 10E-04. This is classified as a low risk. The non- cancer risk ranged from $7.8 \mathrm{E}-05$ to $4.4 \mathrm{E}-02$ for adults and from 9.4E-05 to 5.3E-02 for children for individual compounds (Hazard quotients). The hazard index (HI) was 4.7E-02 for adults and 5.7E-02 for children. According to the United States Environmental Protection Agency, a non- carcinogenic risk is considered significant if $\mathrm{HI}$ is equal to or greater than one [21]. Therefore, the HI values which were established in this study for both adults and children suggest that the noncancer risk associated with the consumption of contaminated fish species from Lake Victoria is insignificant.

Table 4. Cancer and Non- cancer risks associated with consumption of studied fish species.

\begin{tabular}{lllll}
\hline \multirow{2}{*}{ OCPs } & \multicolumn{2}{l}{ Cancer risks } & \multicolumn{2}{l}{ Non- cancer risks } \\
\cline { 2 - 5 } & Adults & Children & Adults & Children \\
\hline Aldrin & $3.6 \mathrm{E}-06$ & $8.6 \mathrm{E}-06$ & $7.1 \mathrm{E}-04$ & $8.6 \mathrm{E}-04$ \\
Dieldrin & $1.1 \mathrm{E}-05$ & $2.7 \mathrm{E}-05$ & $2.2 \mathrm{E}-03$ & $2.7 \mathrm{E}-03$ \\
$\beta-\mathrm{HCH}$ & $1.3 \mathrm{E}-05$ & $3.2 \mathrm{E}-05$ & $4.4 \mathrm{E}-02$ & $5.3 \mathrm{E}-02$ \\
$\mathrm{HCB}$ & $6.2 \mathrm{E}-06$ & $1.5 \mathrm{E}-05$ & $7.8 \mathrm{E}-05$ & $9.4 \mathrm{E}-05$ \\
$\mathrm{HI}$ & & & $4.7 \mathrm{E}-02$ & $5.7 \mathrm{E}-02$ \\
\hline
\end{tabular}

\section{Conclusion and Recommendations}

The present study is considered to be the first of its kind to report detailed information on the levels of OCPs and PCBs in two commercial fish species namely $L$. niloticus and $O$. niloticus from Lake Victoria, Tanzania. The concentration values of the contaminants were lower than the levels reported in literature elsewhere and below the MRL which is recommended by International statutory agencies. Cancer and non- cancer risks which are associated with the consumption of fresh fish from Lake Victoria were ranked low and insignificant. The results herein suggest that the fish from Lake Victoria in Tanzania are safe for human consumption with regards to organochlorine compounds but calls for continuous monitoring to avoid building up of the compounds in the food chain.

\section{Acknowledgements}

The authors gratefully acknowledge the support of Innovations and Markets for Lake Victoria Fisheries (IMLAF) Project (DFC File No. 14 - P01 - TAN) for the study grant extended to Alex Wenaty through a collaborative research with Sokoine University of Agriculture, Nelson Mandela African Institution of Science and Technology, the University of Copenhagen and Denmark Technical University. We also thank Mr. Donny Thomas, Mr. John Kilian Koddy and Ms. Elinjiwanza Mshiu of the National Fish Quality Control Laboratory for technical assistance during sample collection and extractions for organochlorine compounds analysis.

\section{Conflict of Interest}

There is no conflict of interest.

\section{References}

[1] Bouwman, H. (2004). South Africa and the Stockholm convention on persistent organic pollutants. S. Afr. J. Sci, 100: 323-328.

[2] Wasswa, J., Kiremire, B. T., Nkedi-Kizza, P., Mbabazi, J., \& Ssebugere, P. (2011). Organochlorine pesticide residues in sediments from the Uganda side of Lake Victoria. Chemosphere, 82(1): 130-136.

[3] Darko, G., Akoto, A., Lowor, S., \& Yeboah, P. (2008). Persistent organochlorine pesticide in Fish, Sediments and Water from Lake Bosomtwi, Ghana. Chemosphere, 72 (1): 21 -24 .

[4] Ogwok, P., Muyonga, J. H., \& Sserunjogi, M. L. (2009). Pesticide residues and heavy metals in Lake Victoria Nile perch, Lates niloticus, belly flap oil. Bull. Environ. Contam. Toxicol, 82: 529-533.

[5] Ssebugere, P., Kiremire, B. T., Kishimba, M., Wandiga, S. O., Nyanzi, S. A., \& Wasswa, J. (2009). DDT and metabolites in fish from Lake Edward, Uganda. Chemosphere, 76: 212 - 215.

[6] Polder, A., Muller, M. B., Lyche, J. L., Mdegela, R. H., Nonga, H. E., Mabiki, F. P., Mbise, T. J., Skaare, J. U., Sandvik, M., Skjerve, E., \& Lie, E. (2014). Levels and patterns of persistent organic pollutants (POPs) in tilapia (Oreochromis $s p$ ) from four different lakes in Tanzania: Geographical differences and implications for human health. Science of the Total Environment, 488- 489: 252- 260. 
[7] Henry, L., \& Kishimba, M. A. (2002). Levels of Pesticide residues in Water, Soil and Sediments from Southern Lake Victoria and its Basin. Tanz. J. Sci, 29(1): 77 - 89.

[8] Henry, L., \& Kishimba, M. A. (2006). Pesticide residues in Nile tilapia (Oreochromis niloticus) and Nile perch (Lates niloticus) from Southern Lake Victoria, Tanzania. Environmental Pollution, 140(2): 348 - 354.

[9] Ssebugere, P., Sillanpa, M., Wang, P., Li, Y., Kiremire, B. T., Kasozi, G. N., Zhu, C., Ren, D., Zhu, N., Zhang, H., Shang, H., Zhang, Q., \& Jiang, G. (2014a). Polychlorinated biphenyls in sediments and fish species from the Murchison Bay of Lake Victoria, Uganda. Science of the Total Environment, 482 - 483: $349-357$.

[10] Ssebugere, P., Sillanpa, M., Kiremire, B. T., Kasozi, G. N., Wang, P., Sojinu, S. O.,Otieno, P. O., Zhu, N., Zhu, C., Zhang, H., Shang, H., Ren, D., Li, Y., Zhang, Q., \& Jiang, G.(2014b). Polychlorinated biphenyls and hexachlorocyclohexanes in sediments and fish species from the Napoleon Gulf of Lake Victoria, Uganda. Science of the Total Environment, 481: 55 60.

[11] Oluoch-Otiego, J., Oyoo-Okoti, E., Kiptoo, K. K. G., Chemoiwa, E. J., Ngugi, C. C., Simiyu, G., Omutange, E. S., Ngure, V., \& Opiyo, M. A. (2016). PCBs in fish and their cestode parasites in Lake Victoria. Environ Monit Assess; 188:483.

[12] Afful, S., Awudza, JAM., Osae, S., \& Twumasi, S. K. (2013). Persistent Organochlorine Compounds in the Water and Sediment Samples from Lake Bosomtwe in Ghana. American Chemical Science Journal, 3(4): 434 - 448.

[13] Laskowski, D. A. (2002). Physical and Chemical properties of Pyrethroids. Rev Environ Contam Toxicol, 174: 49 -170.

[14] Anastassiades, M., Lehotay, S. J., Stajnbaher, D., \& Schenck, F. J. (2003). Fast and Easy Multiresidue Method Employing Acetonitrile Extraction/Partitioning and "Dispersive SolidPhase Extraction" for the Determination of Pesticide Residues in Produce. J. AOAC Int, 86: 412-431.

[15] Kasozi, G. N., Kiremire, B. T., Bugenyi, F. W. B., Kirsch, N.H., \& Nkedi - Kizza, P. (2006). Organochlorine Residues in Fish and Water Samples from Lake Victoria, Uganda. $J$. Environ. Qual, 35: 584 - 589.

[16] USEPA. (1997). Exposure factors handbook-general factors. EPA/600/P- 95/002Fa, Vol. I. Office of Research and Development. National Center for Environmental Assessment. U. S. Environmental Protection Agency. Washington, DC.

[17] USEPA. (2009). Risk assessment guidance for superfund. Human Health Evaluation Manual (F, Supplemental guidance for inhalation risk assessment). EPA/540/R/070/002, Vol. I. Environmental Protection Agency, Washington, DC.

[18] Man, Y. B., Kand, Y., Wang, H. S., Lau, W., Li, H., Sun, X. L., Giesy, J. P., Chow, K. L., \& Wong, M. H. (2013). Cancer risk assessments of Hong Kong Soils contaminated by Polycyclic Aromatic Hydrocarbons. Journal of Hazardous Materials, 261: 770 - 776.

[19] USEPA. (1989). Risk Assessment Guidance for Superfund (RAGS), Volume I: Human Health Evaluation Manual (Part F, Supplemental Guidance for Inhalation Risk Assessment). Human health evaluation manual. EPA/540/1-89/002, Vol. I. Office of Solid Waste and Emergency Response. U. S. Environmental Protection Agency. Washington, DC.
[20] Ge, J., Woodward, L. A., Li, Q. X., \& Wang, J. (2013). Composition, distribution and risk assessment of organochlorine pesticides in soils from the Midway Atoll, North Pacific Ocean. Sci. Total Environ, 452-453:421-426.

[21] USEPA. (2001). Supplemental guidance for developing soil screening levels for superfund sites. OSWER 9355.424.Office of Solid Waste and Emergency Response. U. S. Environmental Protection Agency.

[22] ATSDR. (1995). Public Health Assessment. Johnstown City Landfill, Johnstown, Fulton Country. CERCLIS NO. NYD980506927. In: Dep. of Health and Human Services PHS, Atlanta, New York State Dep. of Health under cooperative agreement with the Agency for Toxic Substances and Disease Registry, Atlanta, GA.

[23] Wang, J., Caccamise, S. A. L., Wu, L., Woodward, L. A., \& Li, Q. X. (2011). Spatial distribution of organochlorine contaminants in soil, sediment, and fish in Bikini and Enewetak Atolls of the Marshall Islands, Pacific Ocean. Chemosphere, 84(7): 1002-1008.

[24] Sullam, K. E., Essinger, S. D., Lozupone, C. A., O`Connor, M. P., Rosen, G. L., Knight, R. O. B., Kilham, S. S., \& Russell, J. A.(2012). Environmental and ecological factors that shape the gut bacterial communities of fish: A metaanalysis. Molecular Ecology, 21(13): 3363-3378.

[25] Kim, S. K., Oh, J. R., Shim, W. J., Lee, O. H., Lim, U. H., Hong, S. H., Shin, W. B., \& Lee, D. S. (2002). Geographical distribution and accumulation features of organochlorine residues in bivalves from Coastal areas of South Korea. Marine Pollution Bulletin, 45 (1 - 12): 268 - 279.

[26] Lalah, J. O., Yugi, P. O., Jumba, I. O., \& Wandiga, S. O. (2003). Organochlorine pesticides in Tana and Sabaki Rivers in Kenya. Bulletin of Environmental Contamination and Toxicology, 71 (2): $0298-0307$.

[27] Yi, Z., Guo, P., Zheng, L., Huang, X., \& Bi, J. (2013). Distribution of HCHs and DDTs in the soil-plant system in tea gardens in Fujian, a major tea-producing province in China. Agric Ecosyst Environ, 171:19-24.

[28] FAO/WHO. (1997). Codex maximum residual limits for pesticides. $F A O / W H O$, Rome Italy.

[29] Kannan, K., Tanabe, S., \& Tatsukawa, R. (1995). Geographical distribution and accumulation features of organochlorine residues in fish in tropical Asia and Oceania. Environ. Sci. Tech, 29: 2673-2683.

[30] URT. (2005). The United Republic of Tanzania, National Implementation Plan (NIP) for the Stockholm Convention on Persistent Organic Pollutants (POPs), Vice President's Office, Division of Environment, Dar es Salaam.

[31] Madadi, O. V., Wandiga, S. O., \& Jumba, I. O. (2006). The status of persistent organic pollutants in Lake Victoria catchment. In: Odada, E. O., \& Daniel, O. (Eds.), Proceedings of the 11th World Lakes Conference, vol. 2, pp. 107-112.

[32] Witczak A., \& Tomza- Marciniak A. (2010). The health risk assessment of organochlorine pesticides in smoked fish products available in Szczecin, Poland. Journal of Environmental Science and Health, Part B, 45: 658 - 665. 